TITLE:

\title{
Ultrasonic Propagation in Nickel and Mn-ferrite at High Magnetic Fields(Abstract_要旨)
}

\section{$\operatorname{AUTHOR}(\mathrm{S}):$}

Sakurai, Junji

\section{CITATION:}

Sakurai, Junji. Ultrasonic Propagation in Nickel and Mn-ferrite at High Magnetic Fields. 京 都大学, 1964, 理学博士

ISSUE DATE:

1964-03-23

URL:

http://hdl.handle.net/2433/211255

RIGHT: 


\section{【27】}

\section{氏名}

学位の種 類

学 位記 番号

学位授与の日付

学位授与の要件

研究科. 専攻

学位論文題目

論文調査委員

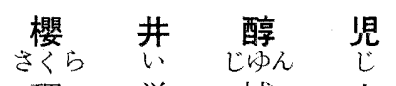

理 学 博士

理 博 第 77 号

昭和 39 年 3 月 23 日

学位規則第 5 条第 1 項該当

理学 研 究科化学 専 攻

\section{Ultrasonic Propagation in Nickel and Mn-ferrite at High Magnetic Fields}

(高い磁場に扣けるニッケルとマンガンフェライト中の 超音波の伝わり方）

教主授查），秀夫教授山本常信 教授可知鿆次

\section{論 文内容 $の$ 要旨}

強磁性体の弾性的性質については数多くの研究があるが，そのほとんどが飽和磁化までの比較的弱い磁 場に括ける現象を扱っている。飽和磁化後の強い磁場に括いて里らはニッケル単結晶を用い, 磁場の方向 や大きさ等により超音波速度と減衰率 $(\boldsymbol{D})$ に $10^{-4}$ 程度のかなり小さい変化のあることを見出し, Simon はこれを次のように説明した。超音波が強磁性体を通るとき，その速度変化は磁歪による附加的歪によっ て生じ，またその減衰率は，附加的歪に伴う磁化方向のわずかな回転から渦電流が発生することによるの である。この理論は里らの実験結果をよく説明しているが，里らの実験は部分的なものである。ここに拉 いて著者は, 試料, 実験条件を変え, 測定精度を上げて広範なデータを求め, あわせて Simonの理論を 検証している。

超音波速度を測定するためには，周波数変調方式による超音波共振法の装置を試作し，その音速測定の 感度は $5 \times 10^{-6}$ の高いものである。超音波減衰率の測定にはパルス方式によるスペリー超音波減衰率测定 器を用い，その周波数範囲は 5 65 Mc/sec である。試料はニッケルのほかニッケル銅合金とマンガンフ ェライトを用いている。いずれも〔001]または〔110]方向に切り出された円筒状単結晶であり，直径 1.5 $\sim 3 \mathrm{~cm}$, 高さ $1 \sim 1.5 \mathrm{~cm}$ の寸法をもっている。上下の底面は高い平滑度と平行度を要し, 数ミクロン以内 の精度に仕上げている。超音波は主に横波を用いている。著者が得た主な絬果を列挙すると，

（1）〔001]力向のニッケル単結晶の結晶方位に対して, 大きさ一定の磁場の磁場方向を变えると, 超 音波速度はある結晶方位と磁場のなす角度の余弦で表わし得る変化をなし, 主要面に㧤いては 2 回対 称, 4 回対称等の対称性を示す。その比例定数はSimon の理論に上ると, 弾性定数, 磁歪定数, 飽 和磁化の強さ, 磁場の強さを含さが，実験值はその理論值とよく一致している。〔110〕力向のニッケ ル単結晶については里らにより測定されて括り，著者の測定とよく一致している。

（2）二ッケル単結晶に対して磁場方向が一定のとき，超音波速度の变化は，5２0 koe の大きさの磁 場範囲で, 磁場の大きさに逆比例している。これは Simon の理論と一致している。特別の場合とし 
てある磁場方向では超音波速度の変化が実験䛊差以内にて認められなかった。これは強制（あるいは 体積）磁雨による速度変化がないことを示している。

（3）二ッケルの単結晶に対して磁場方向を变えると, 超音波速度の変化に伴って減衰率も变わる。減 衰率は超音波の周波数に対し緩和型を示し，その特性周波数は理諭值とょく一致しているが減衰率の 実験值は理論值より 1 桁大さい。この原因について 2，3 検討しているが明らかでない。

(4) ニッケル銅合金についても，ニッケルの場合と類似の変化が観測されている。

（5）マンガンフェライトは超音波速度に関してはニッケルと類似の変化をするが，ある場侖には速度 変化がきわめて小さい。このことは, Simon の理論から，これに関与寸る磁歪定数がきわめて小さい ことから了解される。減衰率に関しては，結晶方向に対する磁場の方位を变えても，実験誤差以内で 変化がない。これは理論にしたがえば，マンガンフェライトの電気抵抗が，ニッケルとは対照的に桁 ちがいに大きく，したがって渦電流がきわめて小さいことで説明される。

参考論文との 1 は，面心立方格子型であるニッケル鉄・ニッケル銅合金について，弾性定数と広い範囲 にわたる組成との関係を求め，原子間の相互作用の観点上り論じたもので，この種の研究は余り行われて いない。その 2 特よびその 3 は $\mathrm{Na} \mathrm{Cl}$ 型の遷移金属炭化物の熱伝導とホール効果についての研究であり, 4 族，5族の遷移金属の炭化物につき電気抵抗とホール効果の測定より 1 带近似により伝導電子の濃度を 求め，その結果，伝導帯は 4 族炭化物では汪とんど空であり，5族炭化物では 1 分子当たり約 1 個の電子 で占められていること，また熱伝導度と電気伝導度より求めたウィーデマン・フランツ比の考察により， これらの炭化物では格子による熱伝導が非常に大きいことを導き出している。

\section{論文審査の結 果の要旨}

強磁性体の弾性的性質については今までに多くの研究があるが，その注とえぞは，磁場をかけると強磁 性体の弾性率が増加する現象，いわゆる $\Delta E$ 効果に関しての研究である。これは比較的弱い磁場に执いて 磁区の配列が变化することと密接に関連して抢り，したがってこれを定量的に理論づけることには限界が あった。一方, 強い磁場に和ける, すなわち一応磁化飽和したのちの弾性的性質についての研究は少なく, わずかに里らの実験とそれを説明した Simon の理論があるのみである。里らは、ニッケルの単結晶を用 いて，超音波の速度と減衰率に，磁場の方向や大きさ等によって，いわゆる $\Delta \mathrm{E}$ 效果比べるとかなり小 さいが，変化のあることを見出した。Simonはこれを磁歪と，磁化方向の回転による渦電流とによって説 明した。ところで，この種の実験では単結晶を用いる必要があり，その結晶方位に対して超音波の入射方 向とその振動方向, 磁場の方向が問題となり，磁場の大きさおよび超音波の振動数を变学る必要があり， 測定精度の問題もあって，里らの実験はかなり部分的である。そこで著者は試料，実験条件を変点，測定 精度を上げてより広範なデータを求め，あわせて Simon の理詇を檢討したのである。

試料はニッケルの汪か, ニッケル銅合金とマンガンフェライトを採りあげているが, マンガンフェライト はその磁歪定数の一つがきわめて小さい值をもち，電気抵抗は金属と対照的にきわめて大きい值をもって 牤り, 理論の検討の点から與味深い試料である。測定精度を上げるため, 直径 $1.5 \sim 3.0 \mathrm{~cm}$ の円筒状の大き い単結晶を製作し，上下の底面の平滑度と平行度は特に精度を上げ，数ミクロン以内に仕上げている。超 
音波速度の測定には，周波数変調方式による超音波共振法の装置を試作し，音速測定の感度は $5 \times 10^{-6}$ 程 度の高いものを得ている。この感度を用いることによって次の結果を得ることに成功している。すなわち， ニッケルの単結晶に対し磁場方向が一定のときに, 超音波の速度の変化が; 5 20koe の磁場範围で, 磁 場の大ささに逆比例することである。その特殊の場合として，市る磁場方向では磁場の大きさに関係なく 速度が一定であることで，このことは強制磁丕が速度変化に影響を及洼さないことを示唆している。減衰 率の測定には 5 65 Mc/sec の周波数を用いているが, ニッケルの減衰率はこの範囲の周波数に対し緩和 型を示すことを見出した。その特性周波数は理論值とよい一致をしている。減衰率の大きさは理論値より 一桁大きいが，これの原因は明らかでない。マンガンフェライトの減衰率は電気抵抗が金属とちがってき わめて大きいので, 渦電流が非常に小さく，したがって減衰率がほとんど零に近いことが予想されるが， 実験の結果も実験誤差以内で变化が認められていない。またマンガンフェライトの磁歪定数の一つは非常 に小さいので, 超音波の入射方向と振動方向を適当に兄らべば，卡の速度変化はきわ女て小さいはずであ り, 測定結果はこれとよく一致している。な预磁場方向をいくつかの主要面で変えた場合, 超音波速度が 変化する様子を詳しく求めている。

参考論文その 1 は, 二元合金系の弾性定数を求め, 異種原子間の相互作用との関係を論じたものであり, その 2 とその 3 快遷移金属炭化物の熱伝導とホール効果に関するもので，ともに興味深い労作である。

要するに, 著者桜井醇児は典型的な 2,3 の強磁性体について強磁場に和ける磁気弾性効果を, 実験条 件を広く, 測定精度を上げて詳しく求め, 理論的検討を行なったもので, 強磁性随伴現象の研究分野に拉 いて重要な貢献をし，今後の発展に大きい示唆を与をたのであって，磁性を含む物性について豊富な知識 そすぐれた研究能力をもっていることが認められる。

よって本論文は理学博士の学位論文として価値があるものと認める。 